Nadtochii V., Nadtoshyi A.

\title{
METHODS FOR ENSURING THE NAVIGATION SAFETY OF UNMANNED SURFACE VESSEL
}

При створенні безекіпажних надводних суден (БНС), особливу увагу приділяють безпеці мореплавства. Однією з основних загроз на морі є загроза зіткнення. Можна виділити два основних напрямки забезпечення безпеки мореплавства. Перший - це юридичне регулювання $і$ низка міжнародних документів, які є обов'язковими для виконання усіма судновласниками. Другий - це технічні системи керування та програмне забезпечення, призначенням яких є забезпечення безпеки мореплавства. Дана робота присвячена питанню визначення рівня небезпеки зіткнення та реакцї на ию небезпеку зі сторони системи автоматичного керування курсом та швидкістю БНС, яка виступає у ролі об'єкта дослідження. Предметом дослідження є процеси та алгоритми керування. Зважаючи на суттєву небезпеку, яку можуть представляти автоматичні рухомі системи на морі, питання безпеки мореплавства мають пріоритетне значення.

Аналіз ефективних систем керування автономними рухомими засобами показує, що їх створення грунтується на відносно простих, але достатньо точних абстрактних моделях взаємодіючих середовищ, (фізичних та інформаційних). Такі моделі є відправною точкою створення автоматизованих та автоматичних систем, до яких у тому числі відносяться і БНС. Звертаючи увагу на технічну сторону проблеми необхідно зазначити, що визначення рівня небезпеки та реакція на неї зі сторони системи керування БНС також вимагае певної формалізації.

В даній роботі запропоновано спосіб визначення небезпеки зіткнення БНС з іншими рухомими та нерухомими морськими об'єктами. Визначено узагальнений алгоритм роботи системи керування курсом та швидкістю БНС. Визначено реакиія рушійної (пропульсивної) системи та необхідний склад бортового обладнання для забезпечення безпеки мореплавства. Необхідно зазначити, що в роботі під БНС маються на увазі малотоннажні (до $1 \mathrm{~m}$ ) надводні самохідні плавзасоби типу човен або катер.

Результати дослідження стануть у нагоді при побудові систем керування на основі нечітких або нейро-нечітких контролерів.

Ключові слова: безпека мореплавства, безекіпажне надводне судно, рушійно-кермовий комплекс, керування курсом судна, керування швидкістю судна, автокермовий.

Received date: 17.09.2019

Accepted date: 14.10.2019

Published date: 30.12.2019
Copyright (C) 2019, Nadtochii V., Nadtoshyi A. This is an open access article under the CC BY license (http://creativecommons.org/licenses/by/4.0)

\section{Introduction}

The goal of creating unmanned surface vessels (USV) is increasing the effectiveness of state regulation in such an important area as environmental protection and monitoring the environmental safety of water areas and coastal zones. In addition, USV can be used to protect protected water areas, hydraulic structures and communications, as well as sunken historical monuments. With the help of USV, hydrographic work can be performed (mapping the bottom surface, controlling the depth of fairways, straits), search and rescue operations, exploration of natural resources, and the like. But when using USV in any of the above cases, it is necessary to ensure their safe and trouble-free operation. The main danger at sea is the threat of collision with other objects. It can be other watercraft, hydraulic structures (bridge supports, breakwaters, lighthouses), navigation aids (buoys), natural formations (rocks, shallows), coastline. To prevent the risk of collision, determining the degree of danger and how to reduce it is important.
As evidenced by numerous information sources, this problem is actively discussed by all stakeholders around the world. There are many approaches and solutions. In [1], a modern overview of various approaches to preventing collisions with several unmanned aerial vehicles is presented, as well as a classification according to the algorithms and structures used, their main features are discussed. In [2], the option of installing a specialized radio navigation system for collision warning on all ships of the world is considered. In [3], it is noted that the development of a high-level autonomous collision avoidance system for ships operating in an unstructured and unpredictable environment is a complex task. The authors propose solutions to this problem by establishing intelligent control systems based on neural networks that are pre-trained in difficult situations and tested in real-life conditions. In work [4] of the SACAS system (shipborne autonomous collision avoidance system), an architecture of parallel trajectory planning is proposed. Such a system includes a scheduler based on a modified RRT (a rapidly exploring random tree) algorithm designed to find the optimal global 
trajectory at a low re-scheduling frequency. The system also contains a scheduler based on a modified DW (Dynamic Window) algorithm. The latter is used for parallel trajectory planning in order to generate an optimal local trajectory at a high redevelopment frequency and to counteract the unexpected behavior of dynamic obstacles in the immediate vicinity of the vessel. Numerous studies of maritime safety related to solving specific problems [5, 6], where the problems of creating automatic motion control systems for unmanned boats and other self-propelled surface vehicles (USV Unmanned surface vehicle) are solved. Separate studies [7] prove that humans can be a key factor in successfully preventing collisions in future operations using MASS (maritime surface autonomous ships). Thus, at the moment there is no single approach to solving the problem of navigation safety. Search and development of effective systems for preventing collisions at sea is also part of the subject matter of such scientific developments [8]. The need to create such systems is due to the constant increase in the number of autonomous vessels in the vast oceans [9].

Therefore, it is urgent to develop a method for ensuring the safety of navigation for unmanned surface vessels.

Thus, the object of study is an unmanned surface vessel. And the purpose of the work is to establish a method for determining the level of danger of collision of the unmanned surface vessel with other moving and stationary marine objects, engineering structures and natural formations.

\section{Methods of research}

Obviously, for the safety of USV navigation, it is necessary to give the control system (CS) of the ability to preidentify obstacles that are or may arise on the trajectory of its movement and actively evade them. It is important that the process of avoiding obstacles ends with the restoration of the main task. To do this, it is necessary to equip the USV CS:

- system of sensors for the effective detection of surface/underwater obstacles;

- reliable and productive computing equipment and peripherals;
- software with algorithms that are based on information from sensors about the environment and mission goals, capable of generating adequate commands to executive devices.

Currently, the most effective sensor systems are considered to be radar stations (radar) for illumination of surface conditions and sonar stations (SS) for illumination of underwater environment. It is also possible to use lidar (laser scanners) and vision systems in various optical ranges. These sensor systems must satisfy a number of conditions, but the main ones are the detection range, the resolution in range and the angle resolution of the obstacle.

The main actuator is the propulsion-steering complex (PSC), which should ensure the movement of the USV from the fluid spatial coordinate of the given spatial coordinate along a given path and a given period of time taking into account external disturbances.

The choice of engine type for the USV is a complex scientific, technical and engineering task, the solution of which should provide the necessary speed of the USV movement and its maneuverability. These characteristics directly affect the safety of navigation, but also determine the cost-effectiveness (autonomy), reliability, controllability and compactness of the entire system as a whole (Fig. 1).

An important issue when creating a USV with rowing electric installations (REI) is the choice of power source (PS). Currently, the main sources of electricity for autonomous vehicles are chemical batteries of various types (acidic, alkaline, silver-zinc, nickel-intentional, lithium-intentional). It is necessary to use of fuel (hydrogen-oxygen) elements. As additional sources, smallsized electromechanical converters (for example, a piston engine generator), wind, wave or photoelectric converters can be used.

It is advisable to use combined PSC, which use several power plants with different operating principles and independent energy sources. Such combined PSCs are attractive from the point of view of ensuring high reliability, and also directly affects the safety of navigation.

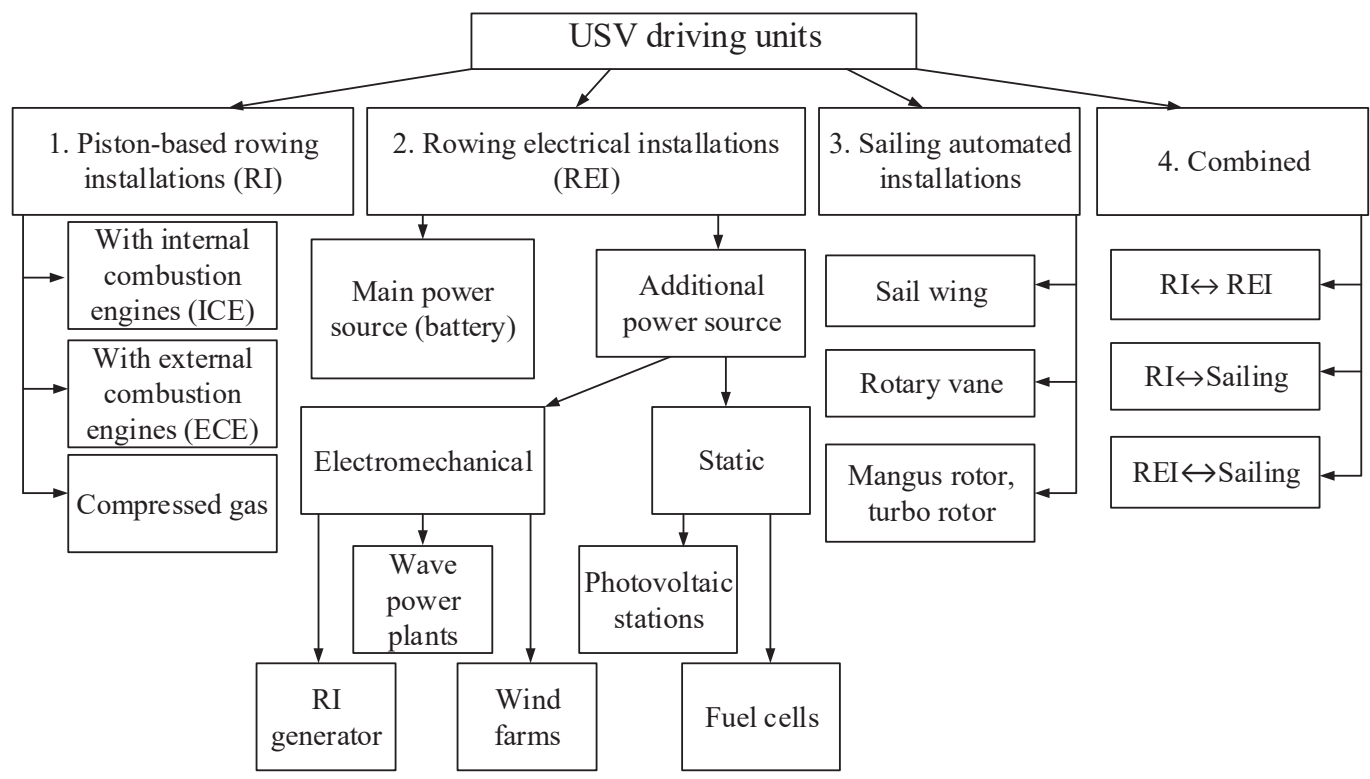

Fig. 1. Types of propulsion and steering complexes (PSC) that can be used in unmanned surface vehicles (USV) 


\section{Research results and discussion}

The general algorithm for the operation of the automatic control system for the USV movement, taking into account the need to ensure the safety of navigation, is shown in Fig. 2. In this algorithm, in a logical condition, operations are performed with the abstract value «danger zone». This is a value that can be determined, given the speed of the object located next to the USV, and the speed of the USV itself. The necessary components for accounting are also the distance and bearing to the object or obstacles. Thus, the term «danger zone» means the area of the water area in which there is a potential threat of collision.

Shown in Fig. 2 algorithm can be simplified if to assume that threats can only be mobile. Fixed marine objects (for example, buoys, rocks, pylons) can be dangerous if the USV moves on them. Therefore, in the algorithm in Fig. 2, it is possible to exclude blocks highlighted in color.

Fig. 3 presents a diagram for determining the level of danger during movement (drift, positioning) of the USV. On the diagram, concentric dashed rings reflect the distance of obstacle detection «D-1»- distant, «D-2»middle and «D-3» - near relative to the USV. Also on the diagram are given sectors (directions) to identify obstacles relative to the USV - «right on course» or «behind the stern», which are marked «0» and «C» on the diagram, respectively. The «straight ahead» sector is divided into two subsectors with an opening angle of $10^{\circ} \ll \mathrm{LO} »$ and $\ll \mathrm{RO} »$. Two subsectors are allocated from the side projections: on the left on the course «L1», on the left on the side - «L2», on the right on the course - «R1» and on the right on the side «R2». Sectors «L1», «R1» have an opening angle of $65^{\circ}$, «L2», «R2», have an opening angle of $70^{\circ}$, $« \mathrm{CL} »$ and $« \mathrm{CR} »$ has an opening angle of $35^{\circ}$. The level of threat of collision (danger level) has three gradations, which are indicated in the diagram by pink, yellow and green colors. Let's consider the hazard level to be increasing from green to pink.

The diagram shown in Fig. 3 may have a different view depending on the operating mode of the USV, its speed or other parameters (weather conditions, sea waves, the presence of currents, etc.), i. e.,

$$
R_{j}=f(V, G, W, \ldots),
$$

where $R_{j}$ - radius of detection of obstacles (D-1, D-2, D-3); $V$ - USV speed; $G$ - force of excitement (for example, on a scale developed by the World Meteorological Organization); $W$ - wind force (for example, on the Beaufort scale).

In addition, the position of the USV in the diagram of Fig. 3 can also be adjusted.

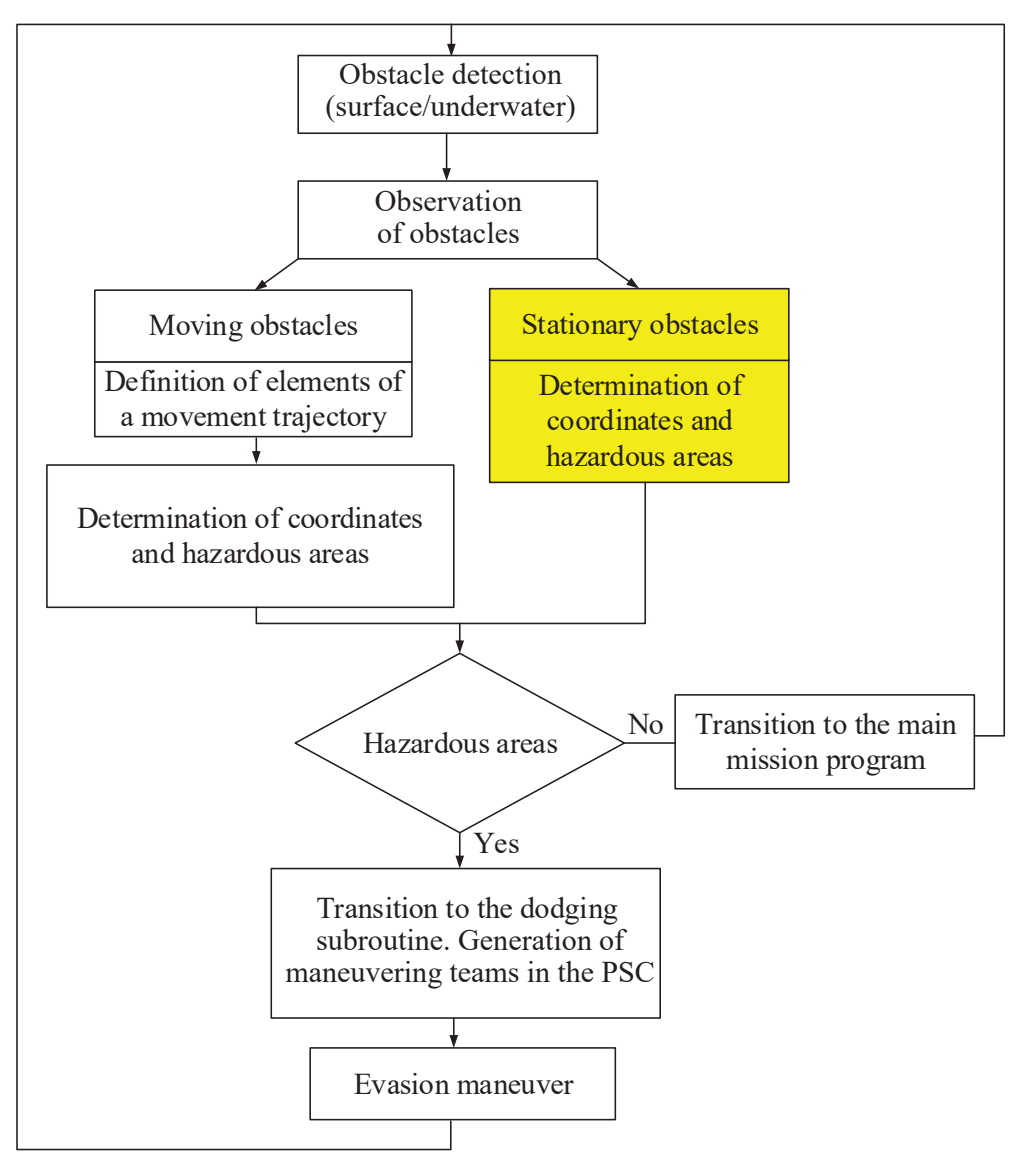

Fig. 2. Variant of the algorithm for ensuring the safety of navigation in unmanned surface vessels (USV)

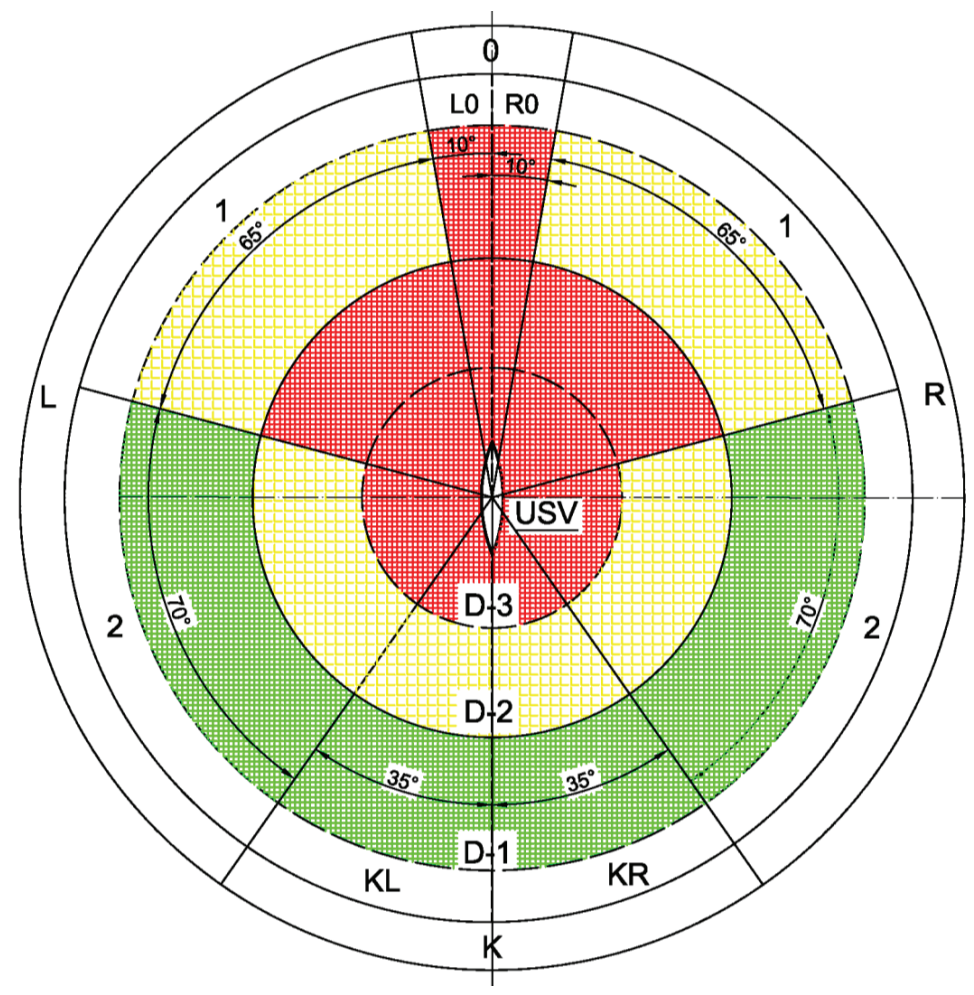

Fig. 3. Determination of the level of danger of obstacles around the unmanned surface vessel (USV) 
According to Fig. 3, it is possible to determine the behavior of the CS, which is considered appropriate to the level of danger. In this case, the following dependencies are valid when moving the USV with respect to the obstacle:

$$
\Delta l=l_{i-1}-l_{i}
$$

where $\Delta l$ - deviation of the radius vector (distance) to the obstacle in the time interval $\Delta t=t_{i-1}-t_{i} ; l_{i-1}-$ radius vector (distance) to the obstacle - preliminary value; $l_{i}-$ radius vector (distance) to the obstacle - current value.

The rate of change of distance (Table 1):

$$
\frac{\Delta l}{\Delta t}=\frac{l_{i-1}-l_{i}}{t_{i-1}-t_{i}} .
$$

It is also necessary to consider bearing on the obstacle relative to its own course:

$$
\Delta \varphi=\varphi_{i-1}-\varphi_{i}
$$

where $\Delta \varphi$ - change in the angle formed by the USV motion vector $\bar{V}$ and the radius vector $\bar{l}$ (distance) to an obstacle in a period of time $\Delta t=t_{i-1}-t_{i} ; \varphi_{i-1}-$ previous value of the angle formed by the USV motion vector $\bar{V}$ and the radius vector $\bar{l}$ of the obstacle; $\varphi_{i}$ - current value of the angle formed by the USV motion vector $\bar{V}$ and the radius vector $\bar{l}$ of the obstacle.

Table 1

Conditions for determining the position of an obstacle relative to unmanned surface vessel (USV) according to the distance deviation

\begin{tabular}{|c|c|l|}
\hline If & $\Delta l>0, \frac{\Delta l}{\Delta t} \geq 0$, & $\begin{array}{l}\text { then the obstacle approaches at a constant } \\
\text { speed or accelerated }\end{array}$ \\
\hline If & $\Delta l=0, \frac{\Delta l}{\Delta t}=0$, & $\begin{array}{l}\text { then the obstacle moves in parallel or as } \\
\text { a satellite }\end{array}$ \\
\hline If & $\Delta l<0, \frac{\Delta l}{\Delta t} \leq 0$, & $\begin{array}{l}\text { then the obstacle is removed at a constant } \\
\text { speed or accelerated }\end{array}$ \\
\hline
\end{tabular}

The angular velocity of the change in direction to the obstacle (Table 2):

$$
\frac{\Delta \varphi}{\Delta t}=\frac{\varphi_{i-1}-\varphi_{i}}{t_{i-1}-t_{i}}
$$

The corresponding graphical representation according to the Tables 1, 2 on the movement of an obstacle relative to the USV is shown in Fig. 4.

Table 2

Conditions for determining the position of the obstacle relative to the unmanned surface vessel (AUV) according to the deviation of the angle of direction to the obstacle

\begin{tabular}{|c|l|l|}
\hline If & $\Delta \varphi>0, \frac{\Delta \varphi}{\Delta t} \geq 0$, & $\begin{array}{l}\text { then the obstacle is ahead of the BN5 and } \\
\text { moves at a constant speed or accelerated }\end{array}$ \\
\hline If & $\Delta \varphi=0, \frac{\Delta \varphi}{\Delta t}=0$, & then the obstacle moves in a parallel course \\
\hline If & $\Delta \varphi<0, \frac{\Delta \varphi}{\Delta t} \leq 0$, & $\begin{array}{l}\text { then the obstacle lags behind the BNS and } \\
\text { moves at a constant speed or slows down }\end{array}$ \\
\hline
\end{tabular}

The main criterion for determining the response of the CS to the danger level with certain parameters of its movement is the USV maneuver in the opposite direction with the corresponding speed. The CS response can be determined by an expert method with their refinement on mathematical models of CS, USV, the environment and obstacle models. The most suitable CSs for calculating the presented positions are systems based on fuzzy or neurofuzzy controllers [10].

The intensity of shipping on sea routes, near ports and sea bases, as well as in the fairways of rivers, canals, channels, is quite high. Therefore, a prerequisite for ensuring the safety of navigation is the CS ability to detect, accompany and respond simultaneously to several obstacles, both surface and underwater.

\section{Conclusions}

In the course of the study, it is found that combined propulsion and steering devices for unmanned vessels enhance navigation safety by duplicating the propulsive function of one propulsion system of the second. In other words, combined PSCs have increased reliability. A hazard chart is also obtained that allows to formally determine the hazard level of identified obstacles. The hazard chart allows to adjust the level of danger taking into account factors such as sea waves, wind strength, speed of USV and the like. In addition, the USV position in the diagram can also change.

It has been established that based on measurements of sensor systems, it is possible to formally determine the position, direction and speed of movement of hazardous areas, and their degree of danger with respect to USV. Based on the information received, in accordance with the laid down collision avoidance subroutine, control commands for the propulsion and steering complex can be generated.

The research results will be useful in constructing control systems based on fuzzy or neuro-fuzzy controllers.

\section{References}

1. Huang, S., Teo, R. S. H., Tan, K. K. (2019). Collision avoidance of multi unmanned aerial vehicles: A review. Annual Reviews in Control, 48, 147-164. doi: http://doi.org/10.1016/ j.arcontrol.2019.10.001 
2. Xie, S., Chu, X., Zheng, M., Liu, C. (2019). Ship predictive collision avoidance method based on an improved beetle antennae search algorithm. Ocean Engineering, 192, 106542 doi: http://doi.org/10.1016/j.oceaneng.2019.106542

3. Zhao, L., Roh, M.-I. (2019). COLREGs-compliant multiship collision avoidance based on deep reinforcement learning. Ocean Engineering, 191, 106436. doi: http://doi.org/10.1016/ j.oceaneng.2019.106436

4. Yang, R., Xu, J., Wang, X., Zhou, Q. (2019). Parallel trajectory planning for shipborne Autonomous collision avoidance system. Applied Ocean Research, 91, 101875. doi: http://doi.org/ 10.1016/j.apor.2019.101875

5. Oh, H. N. H., Tsourdos, A. Savvaris, A. (2014). Development of Collision Avoidance Algorithms for the C-Enduro USV. IFAC Proceedings Volumes, 47 (3), 12174-12181. doi: http:// doi.org/10.3182/20140824-6-za-1003.02362

6. Zhao, Y., Li, W., Shi, P. (2016). A real-time collision avoidance learning system for Unmanned Surface Vessels. Neurocomputing, 182, 255-266. doi: http://doi.org/10.1016/j.neucom.2015.12.028

7. Abilio Ramos, M., Utne, I. B., Mosleh, A. (2019). Collision avoidance on maritime autonomous surface ships: Operators' tasks and human failure events. Safety Science, 116, 33-44. doi: http://doi.org/10.1016/j.ssci.2019.02.038

8. Blincov, V. S. (2007). Sovremennye problemy sozdaniia elektrooborudovaniia i avtomatiki podvodnykh apparatov. Radioelektronni i komp'iuterni sistemi, 5 (24), 90-98.

9. Unmanned Systems Integrated Roadmap 2009-2034 (2009) Department Of Defence United States Of America. Washington, 195. doi: http://doi.org/10.21236/ada522247

10. Leonenkov, A. V. (2005). Nechetkoe modelirovanie v srede $M A T L A B$ i fuzzyNECH. Saint-Peterburg: BVKH-Pererburg, 736.

Nadtochii Victor, PhD, Department of Automation and Electrical Equipment, Kherson Branch of the Admiral Makarov National University of Shipbuilding, Ukraine, e-mail: nva074@gmail.com, ORCID: http://orcid.org/0000-0003-3869-3546

Nadtoshyi Anatolii, PhD, Department of Automation and Electrical Equipment, Kherson Branch of the Admiral Makarov National University of Shipbuilding, Ukraine, e-mail: tasman.leh.85@gmail.com, ORCID: http://orcid.org/0000-0003-1905-0895

DOI: $10.15587 / 2312-8372.2019 .187278$

\section{Holub H., \\ Kulbovskyi I., \\ Skliarenko I., Hannoshyna I., Klochkov Y., Kharuta V.}

RESEARCH ON THE POSSIBILITIES
OF SOLUTION OF THE MONITORING
PROJECTS OF THE RAILWAY POWER
SUPPLY SYSTEM

Об’єктом дослідження є параметри моніторингу системи електропостачання залізничного транспорту. Пристрої реєстрації параметрів роботи об'єктів системи постачання електроенергї PMUs складають основу системи моніторингу перехідних режимів WAMS. Важливим аспектом елементів WAMS є синхронізація даних, яка технологічно забезпечується за допомогою супутникових систем орієнтаціі.

В ході дослідження використовувалися системний аналіз, системний підхід до проблеми, а також способи синхронізацї та систематизацї даних.

Досліджено методи розв'язування задач процесів моніторингу системи електропостачання залізничного транспорту. Функиї діагностики, що в даний час реалізуються за допомогою PMUs, WAMS, фактично зосереджені та обмежені на ділянках електропостачання, $i$ включають в себе моніторинг низькочастотних коливань системних параметрів. А також ідентифікацію аварійного режиму та визначення місця пошкодження в об'єктах системи електропостачання. Крім того, для використання цих функиій, разом з тим, вже при сучасному розвитку систем, необхідним є забезпечення діагностичних функцій в масштабі енергосистем, з мінімізацією участі та впливу людини у формуванні результатів оцінювання режимів. Це пов'язано з тим, що є необхідність розширення діагностичних функцій щодо параметрів об'єктів системи електропостачання, використовуваних систем моніторингу, які дозволять розв'язувати задачі оперативно-диспетчерського управління цих об'єктів.

Завдяки цьому забезпечується можливість розв'язання оперативно-диспетчерських задач, оцінювання та прогнозування стану при обробці інформащї, ї̈ синхронізащї та систематизації. А також спостереження і синхронізащї вимірів за часом, що значно підвищує рівень оперативно-диспетчерського управління режимами роботи об'єктів системи електропостачання. У порівнянні з аналогічними технологіями, нові, засновані на використанні пристроїв РМU для збору даних, мають перевагу перед традиційними технологіями SCADA, які проводили вимірювання об'єктів системи без синхронізації за часом.

ключові слова: система електропостачання, залізничний транспорт, синхронізація даних, комп'ютерні засоби, налаштування інтерфейсу людина-машина.

\section{Introduction}

The solution to the problems of operational management, ensuring reliable, flexible and efficient operation of the power supply system can be achieved when moving to a new level of information support. The functions of time synchronization of data in distributed monitoring systems are most often implemented on the basis of existing 